\title{
Activities of various 6-chloro-6-deoxysugars and $(S) \alpha$-chlorohydrin in producing spermatocoeles in rats and paralysis in mice and in inhibiting glucose metabolism in bull spermatozoa in vitro
}

\author{
W. C. L. Ford and G. M. H. Waites \\ Department of Physiology \& Biochemistry, The University, Whiteknights, Reading RG6 $2 A J$, \\ U.K.
}

\begin{abstract}
Summary. 6-Chloro-6-deoxyglucose, 6-chloro-6-deoxymannose, 6-chloro-6-deoxyfructose, 6-chloro-6-deoxyglucitol, 6-chloro-6-deoxygalactose and $(S) \alpha$-chlorohydrin all produced spermatocoeles in the ductuli efferentes and epididymis of the rat and were neurotoxic in the mouse, but only a-chlorohydrin caused substantial inhibition of glucose metabolism in bull spermatozoa in vitro. The relative potencies of the compounds in producing spermatocoeles reflected their activities as reversible antifertility agents in the rat but compared to the others 6-chloro-6-deoxymannose was considerably less neurotoxic to mice than might have been anticipated from its contraceptive dose. Thus different metabolites may be responsible for causing the antifertility and the neurotoxic effects.
\end{abstract}

\section{Introduction}

$\alpha$-Chlorohydrin (3-chloropropan-1,2-diol: $2.5-10.0 \mathrm{mg} / \mathrm{kg} /$ day) has a reversible antifertility action in the male rat and glycolysis is inhibited in spermatozoa from the cauda epididymidis (see Jones, 1978). $\alpha$-Chlorohydrin will also inhibit glycolysis in spermatozoa exposed to it in vitro (see Ford, Harrison, Takkar \& Waites, 1979). Higher doses of $\alpha$-chlorohydrin $(>25 \mathrm{mg} / \mathrm{kg}$ ) produce spermatocoeles in the efferent ducts or caput epididymidis of the rat (Hoffer, Hamilton \& Fawcett, 1973) and the compound has other toxic effects, including bone marrow depression in rhesus monkeys and calcification of the kidney in rats, which preclude its use for human beings (Kirton, Ericsson, Ray \& Forbes, 1970; Jones, Porter \& Stevenson, 1981; M. R. N. Prasad, personal communication). The ' $S$ ' enantiomer is responsible for the antifertility effect and may be less toxic than the ' $R$ ' enantiomer or the racemic mixture (Jackson \& Robinson, 1976; Ford, Harrison \& Waites, 1977; Jackson, Rooney, Fitzpatrick \& Gibson, 1977).

Several 6-chloro-6-deoxysugars have a reversible antifertility action in the male rat similar to that of $\alpha$-chlorohydrin (Ford \& Waites, 1978a, b; Heitfeld, McRae \& Vickery, 1979). 6-Chloro-6-deoxyglucose has a much higher $\mathrm{LD}_{50}$ than does $\alpha$-chlorohydrin and is an effective contraceptive in the rat and marmoset monkey at doses of $\geq 24 \mathrm{mg} / \mathrm{kg} /$ day, but large single doses $(>200 \mathrm{mg} / \mathrm{kg}$ ) produce spermatocoeles in the rat (Ford \& Waites, 1981). Repeated high doses (480 and $250 \mathrm{mg} / \mathrm{kg} /$ day respectively) are neurotoxic in the mouse (Jacobs \& Ford, 1981) and the marmoset (Jacobs \& Duchen, 1980) and this is often associated with hind-limb paralysis. Therefore this compound is also unsuitable for use by man.

6-Chloro-6-deoxyfructose or 6-chloro-6-deoxyglucitol $(18 \mathrm{mg} / \mathrm{kg} / \mathrm{day})$, 6-chloro-6- 
deoxymannose $(24 \mathrm{mg} / \mathrm{kg} / \mathrm{day})$ and 6-chloro-6-deoxygalactose $(60 \mathrm{mg} / \mathrm{kg} / \mathrm{day})$ all caused an antifertility effect in the male rat similar to that produced by 6 -chloro-6-deoxyglucose $(24$ $\mathrm{mg} / \mathrm{kg} / \mathrm{day}$ ) (Ford et al., 1981). The dosages of each of these compounds and of $(S) \alpha$-chlorohydrin required to produce spermatocoeles in rats or to cause hind-limb paralysis in mice have been compared in the hope that one of them might offer a favourable ratio between the doses needed to produce the contraceptive and the toxic effects. We have also examined the effect of these compounds on glycolysis by bull spermatozoa in vitro.

\section{Materials and Methods}

\section{Antifertility compounds}

$(R S) \alpha$-Chlorohydrin was obtained from Koch-Light Laboratories Ltd (Colnbrook, Bucks SL3 OBZ, U.K.) and was used without further purification. 6-Chloro-6-deoxyglucose, 6-chloro-6-deoxymannose, 6-chloro-6-deoxyfructose, 6-chloro-6-deoxygalactose, 6-chloro-6deoxyglucitol and $(S) \alpha$-chlorohydrin were donated by Dr E. B. Rathbone, Philip Lyle Memorial Research Laboratory, Whiteknights, Reading RG6 2BX, U.K. They were free from discoloration and inorganic chloride. The $\mathrm{pH}$ of a $10 \%(\mathrm{w} / \mathrm{v})$ solution was near neutrality and the compounds appeared $>95 \%$ pure by gas-liquid chromatography (Sweeley, Bentley, Makita \& Wells, 1963) or thin-layer chromatography (chloroform:methanol, $2: 1 \mathrm{v} / \mathrm{v}$, or ethanol :ethyl acetate : water, $5: 45: 1 \mathrm{v} / \mathrm{v}$, on $0.25 \mathrm{~mm}$ layers of silica gel $\mathrm{G}$ ).

\section{Spermatocoele formation in rats}

Male CD rats (Charles River U.K. Ltd, Margate, Kent CT9 4LT, U.K.) of about $350 \mathrm{~g}$ body weight were given a single oral dose of an aqueous solution of the compound under test and killed 3 days later. Spermatocoeles were assumed to be present when the corpus epididymidis was devoid of spermatozoa but in most cases the lesion could be seen clearly.

\section{Neurotoxic effect in mice}

Male CD-1 mice (Charles River U.K. Ltd) of about $35 \mathrm{~g}$ body weight were caged individually and dosed daily for 28 days by oral gavage. They were weighed daily and examined carefully for hind-limb paralysis at the same time (Jacobs \& Ford, 1981). Groups of 5-10 mice were used and each trial included a control group given water and a positive control group given 6-chloro-6-deoxyglucose $(480 \mathrm{mg} / \mathrm{kg} / \mathrm{day})$ except for the trials with $(S) \alpha$-chlorohydrin and 6-chloro-6-deoxygalactose when the positive control group was omitted. In these trials the negative control group received galactose $(1200 \mathrm{mg} / \mathrm{kg} / \mathrm{day})$. The experiment with 6chloro-6-deoxymannose ( 240 or $480 \mathrm{mg} / \mathrm{kg} / \mathrm{day}$ ) was continued for 91 days but the mice were not dosed at weekends after the first 28 days. The fertility of the male mice was tested in the final week of each trial (Jacobs \& Ford, 1981).

\section{Effect on bovine sperm glycolysis in vitro}

Fresh bull semen which narrowly failed to meet the standards imposed for freezing for commercial use in artificial insemination was donated by the Cattle Breeding Centre, Shinfield, Reading, Berkshire. The semen was centrifuged (500 $\mathrm{g}_{\mathrm{av}}, 10 \mathrm{~min}$, room temperature) and spermatozoa were washed once with PBS buffer (Ford et al., 1981). They were resuspended in PBS buffer and $0.8 \mathrm{ml}$ portions $\left(69-94 \times 10^{6}\right.$ cells) were incubated in $10 \mathrm{ml}$ conical flasks sealed with Suba-seal caps for $15 \mathrm{~min}$ at $34^{\circ} \mathrm{C}$ with $0,0.1,1.0,10.0$ or $50.0 \mathrm{~mm}-(R S) \alpha$-chlorohydrin or the same concentrations of one of the 6-chloro-6-deoxysugars or $50 \mathrm{~mm}$-sucrose. Then $0.2 \mathrm{ml}$, 
$10 \mathrm{~mm}-\left[\mathrm{U}-{ }^{14} \mathrm{C}\right.$ lglucose (sp. act. $0.5 \mathrm{Ci} / \mathrm{mol}$ ) was added and the incubation continued for $1 \mathrm{~h}$ when $0.50 \mathrm{ml} 1.0 \mathrm{M}$-perchloric acid was added. The collection of ${ }^{14} \mathrm{CO}_{2}$ and subsequent manipulations were as described by Ford et al. (1981). Each incubation was done in triplicate. Three extra control flasks were acidified at the same time as the glucose was added and it was assumed that these also provided a valid zero time value for the flasks which contained inhibitor. All concentrations of a given compound were tested with the same batch of spermatozoa but different batches were used for each compound. Lactate was assayed by the method of Hohorst (1963).

\section{Results}

\section{Spermatocoele formation}

All the 6-chloro-6-deoxyhexoses, 6-chloro-6-deoxyglucitol and $(S) \alpha$-chlorohydrin produced spermatocoeles in male rats (Table 1). Of the 117 spermatocoeles observed 55 were present in the efferent ducts, 56 in the caput epididymidis, 2 in more distal regions of the duct, and in 4 cases the lesion was not visible but its presence was inferred from the absence of spermatozoa in the corpus epididymidis. There were 18 epididymides with lesions at more than 1 site. The appearance of the spermatocoeles to the naked eye and the relative frequency with which they occurred at the different sites was similar for all the compounds tested.

$(S) \alpha$-Chlorohydrin was the most potent and 6-chloro-6-deoxygalactose the least potent of the compounds screened in producing spermatocoeles. The activities of the remaining compounds were very similar to each other (Table 1 ).

Table 1. The production of spermatocoeles in the efferent ducts and caput epididymidis of rats given a single dose of various 6-chloro-6-deoxysugars or $(S) \alpha$-chlorohydrin

\begin{tabular}{|c|c|c|c|}
\hline & Dose $(\mathrm{mg}(\mathrm{mmol}) / \mathrm{kg})$ & No. of rats & $\begin{array}{c}\text { No. of epididymides } \\
\text { (inc. efferent ducts) } \\
\text { affected }\end{array}$ \\
\hline 6-Chloro-6-deoxyglucose & $\begin{array}{r}120(0.6) \\
180(0.9) \\
240(1.2) \\
480(2.4) \\
1200(6.0)\end{array}$ & $\begin{array}{l}3 \\
3 \\
7 \\
4 \\
4\end{array}$ & $\begin{array}{r}0 \\
0 \\
12 \\
8 \\
8\end{array}$ \\
\hline 6-Chloro-6-deoxyglucitol & $\begin{array}{l}120(0.6) \\
180(0.9) \\
240(1.2) \\
360(1.8)\end{array}$ & $\begin{array}{l}3 \\
3 \\
3 \\
3\end{array}$ & $\begin{array}{l}1 \\
2 \\
5 \\
6\end{array}$ \\
\hline 6-Chloro-6-deoxyfructose & $\begin{array}{l}120(0.6) \\
180(0.9) \\
240(1.2) \\
360(1.8)\end{array}$ & $\begin{array}{l}3 \\
3 \\
3 \\
3\end{array}$ & $\begin{array}{l}1 \\
3 \\
3 \\
6\end{array}$ \\
\hline 6-Chloro-6-deoxymannose & $\begin{array}{l}240(1.2) \\
360(1.8) \\
480(2.4)\end{array}$ & $\begin{array}{l}6 \\
3 \\
3\end{array}$ & $\begin{array}{l}3 \\
6 \\
4\end{array}$ \\
\hline 6-Chloro-6-deoxygalactose & $\begin{array}{r}500(2.5) \\
1000(5.0) \\
1500(7 \cdot 5)\end{array}$ & $\begin{array}{l}3 \\
3 \\
3\end{array}$ & $\begin{array}{l}0 \\
1 \\
4\end{array}$ \\
\hline$(S) \alpha$-Chlorohydrin & $\begin{array}{r}12.5(0.11) \\
25(0.23) \\
50(0.45) \\
100(0.91)\end{array}$ & $\begin{array}{l}3 \\
3 \\
3 \\
3\end{array}$ & $\begin{array}{l}1 \\
4 \\
6 \\
6\end{array}$ \\
\hline$(R S) \alpha$-Chlorohydrin & $100(0.91)$ & 3 & 6 \\
\hline
\end{tabular}




\section{Neurotoxic effect in mice}

The neurotoxic effects of 6-chloro-6-deoxyglucose include partial or complete paralysis of the hind limbs (Jacobs \& Ford, 1981) and similar effects have been noted with $\alpha$-chlorohydrin (Samojlik \& Chang, 1970). In these experiments such signs have been taken as evidence of neurotoxicity. On this criterion all the compounds tested proved to be neurotoxic to male mice (Table 2). On a dose-response basis $(S) \alpha$-chlorohydrin was the most toxic with 6-chloro6-deoxymannose or 6-chloro-6-deoxygalactose being the least toxic compound. The compounds which produced paralysis after the shortest period of treatment also produced the most severe signs and the incidence of toxic effects was dependent on the size of the daily dose rather than the cumulative dose given. The results with the positive control groups given 6-chloro-6deoxyglucose $(480 \mathrm{mg} / \mathrm{kg} / \mathrm{day})$ revealed no significant differences in the susceptibility of different batches of mice.

None of the compounds affected the fertility of the male mice so long as paralysis did not prevent the animals from mating.

Table 2. The production of hind-limb paralysis in male mice by 6-chloro-6-deoxysugars or by a-chlorohydrin

\begin{tabular}{|c|c|c|c|c|c|}
\hline \multirow[b]{2}{*}{ Compound } & \multirow[b]{2}{*}{$\begin{array}{c}\text { Dose }(\mathrm{mg} \\
(\mathrm{mmol}) / \mathrm{kg} / \text { day })\end{array}$} & \multirow{2}{*}{$\begin{array}{c}\text { Trial } \\
\text { duration } \\
\text { (days) }\end{array}$} & \multicolumn{2}{|c|}{ No. of mice } & \multirow{2}{*}{$\begin{array}{c}\text { Days of treatment } \\
\text { before paralysis was } \\
\text { observed } \\
\text { (mean + s.e.m.) }\end{array}$} \\
\hline & & & Tested & $\begin{array}{c}\text { With } \\
\text { paralysis }\end{array}$ & \\
\hline 6-Chloro-6-deoxyglucose & $\begin{array}{l}120(0 \cdot 6) \\
240(1 \cdot 2) \\
480(2 \cdot 4)\end{array}$ & $\begin{array}{l}28 \\
28 \\
28\end{array}$ & $\begin{array}{l}10 \\
10 \\
24\end{array}$ & $\begin{array}{r}0 \\
1 \\
13\end{array}$ & $\begin{array}{l}- \\
8 \\
7 \cdot 8 \pm 0.3\end{array}$ \\
\hline 6-Chloro-6-deoxyglucitol & $\begin{array}{l}240(1 \cdot 2) \\
480(2 \cdot 4)\end{array}$ & $\begin{array}{l}28 \\
28\end{array}$ & $\begin{array}{l}8 \\
8\end{array}$ & $\begin{array}{l}0 \\
2\end{array}$ & - \\
\hline 6-Chloro-6-deoxyfructose & $\begin{array}{l}240(1 \cdot 2) \\
480(2 \cdot 4)\end{array}$ & $\begin{array}{l}28 \\
28\end{array}$ & $\begin{array}{l}8 \\
8\end{array}$ & $\begin{array}{l}2 \\
7\end{array}$ & $\begin{array}{l}5 \cdot 5 \\
4 \pm 0.2\end{array}$ \\
\hline$(S) \alpha-C h l o r o h y d r i n$ & $\begin{array}{r}50(0.45) \\
100(0.91)\end{array}$ & $*$ & $\begin{array}{l}8 \\
8\end{array}$ & $\begin{array}{l}8 \\
8\end{array}$ & $\begin{array}{l}4.4 \pm 0.2 \\
2.6 \pm 0.2\end{array}$ \\
\hline$(R S) \alpha$-Chlorohydrin & $100(0.91)$ & * & 8 & 8 & $4 \pm 0$ \\
\hline 6-Chloro-6-deoxymannose & $\begin{array}{r}240(1.2) \\
480(2 \cdot 4) \\
1200(6.0)\end{array}$ & $\begin{array}{l}91 \\
91 \\
28\end{array}$ & $\begin{array}{l}8 \\
8 \\
8\end{array}$ & $\begin{array}{l}0 \\
0 \\
4\end{array}$ & $\begin{array}{l}- \\
\overline{16 \cdot 5 \pm 2.4}\end{array}$ \\
\hline 6-Chloro-6-deoxygalactose & $\begin{array}{r}480(2.4) \\
1200(6.0)\end{array}$ & $\begin{array}{l}28 \\
28\end{array}$ & $\begin{array}{l}8 \\
5\end{array}$ & $\begin{array}{l}0 \\
2\end{array}$ & $\overline{6}$ \\
\hline
\end{tabular}

* Treatment was stopped when all mice became paralysed.

Bovine sperm glycolysis in vitro

There was considerable variation in the rates of glucose metabolism between the different batches of spermatozoa and the results for each experiment have been normalized to give an arbitrary value of 100 for both ${ }^{14} \mathrm{CO}_{2}$ and lactate production in the control incubations (Text-fig. 1). The actual values ( $\mu \mathrm{mol}$ lactate produced $/ \mathrm{h} / 10^{8}$ spermatozoa and nmol-D-[U-14 $\left.\mathrm{C}\right]$ glucose converted to ${ }^{14} \mathrm{CO}_{2} / \mathrm{h} / 10^{8}$ spermatozoa) were: $(R S) \alpha$-chlorohydrin and sucrose, $0.24 \pm 0.04$ and $12.9 \pm 0.6 ; 6$-chloro-6-deoxyglucose, $0.17 \pm 0.04$ and $6.9 \pm 0.3$; 6-chloro-6deoxyfructose, $0.26 \pm 0.03$ and $20.8 \pm 1.0 ; 6$-chloro-6-deoxyglucitol, $0.41 \pm 0.03$ and $15.1 \pm$ 1.0; 6-chloro-6-deoxymannose, $0.29 \pm 0.03$ and $13.3 \pm 1 \cdot 2$. Lactate production was calculated by subtracting the amount present at the start of incubation from that present at the end. 
Spermatozoa can metabolize lactate so that when lactate production is inhibited it is possible for the lactate concentration to decline during the incubation and so to yield a negative value for lactate production.
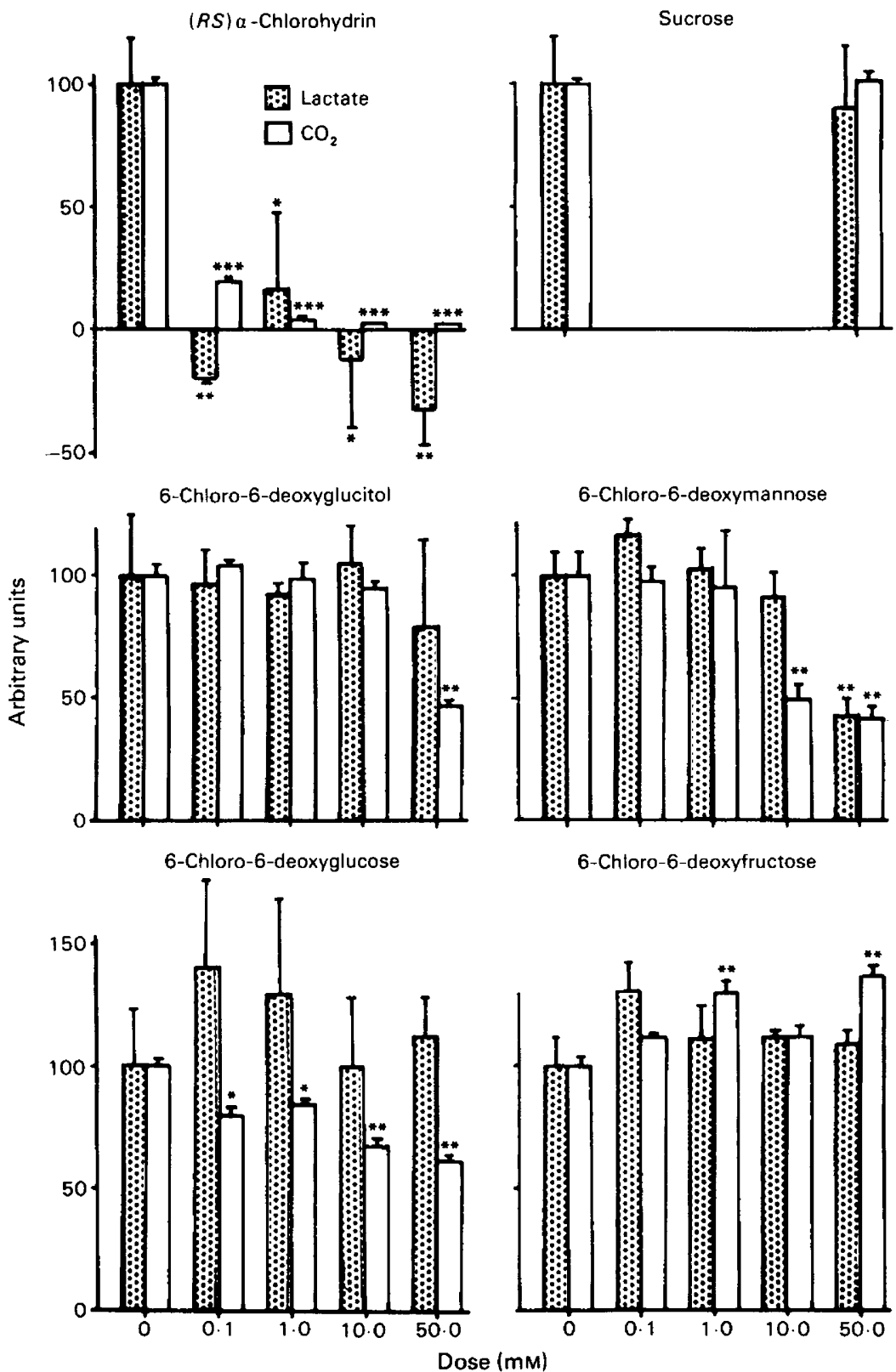

Text-fig. 1. The production of lactate and of ${ }^{14} \mathrm{CO}_{2}$ from $\left.2 \mathrm{~mm} \mathrm{D}-\left[\mathrm{U}-{ }^{14} \mathrm{C}\right] \mathrm{g}\right]$ ucose by bovine spermatozoa in the presence of various 6-chloro-6-deoxysugars or $(R S) \alpha$-chlorohydrin. The results have been normalized to give an arbitrary value of 100 in the control incubations for each compound. Significantly different from corresponding control, ${ }^{*} P<0.05 ;{ }^{* *} P<0.01$; ${ }^{* * *} P<$ 0.001 (paired $t$ test). 
The production of lactate from $2 \mathrm{~mm}$-D-glucose by bovine ejaculated spermatozoa was completely inhibited by $0.1 \mathrm{mM}-(R S) \alpha$-chlorohydrin and the production of ${ }^{14} \mathrm{CO}_{2}$ was markedly decreased under these conditions. Maximal inhibition of ${ }^{14} \mathrm{CO}_{2}$ production was caused by 1.0 mM- $(R S) \alpha$-chlorohydrin (Text-fig. 1). By contrast no changes of comparable size were produced by the 6-chloro-6-deoxysugars or 6-chloro-6-deoxyglucitol. At a concentration of $10 \mathrm{~mm}$ 6-chloro-6-deoxymannose decreased ${ }^{14} \mathrm{CO}_{2}$ production by about $50 \%$ and $50 \mathrm{~mm}$-6-chloro6-deoxymannose inhibited both lactate and ${ }^{14} \mathrm{CO}_{2}$ production by $>50 \%$. 6-Chloro-6deoxyglucitol at $50 \mathrm{~mm}$ inhibited ${ }^{14} \mathrm{CO}_{2}$ production by $45 \%$. These inhibitions were not due to an osmotic effect because $50 \mathrm{~mm}$-sucrose had no effect. 6-Chloro-6-deoxyglucose caused a moderate but statistically significant decrease in ${ }^{14} \mathrm{CO}_{2}$ generation which was dose related (range 14-39\%) but had no effect on lactate production. By contrast some concentrations of 6-chloro-6-deoxyfructose appeared to stimulate the production of ${ }^{14} \mathrm{CO}_{2}$.

\section{Discussion}

All the compounds tested produced spermatocoeles in the rat and were neurotoxic in the mouse; therefore none of them is suitable for development as a contraceptive for human use.

These experiments demonstrate that bull spermatozoa are as sensitive to the antiglycolytic effect of $\alpha$-chlorohydrin in vitro, as those of the ram (Brown-Woodman, Mohri, Mohri, Suter \& White, 1978) and boar (Hutton, Dawson \& Jones, 1980). Nevertheless, although 6-chloro-6deoxysugars had some significant effects on glucose metabolism by these cells the degree of inhibition was always much less than that caused by $\alpha$-chlorohydrin. This provides further evidence that the 6-chloro-6-deoxysugars must be metabolized in vivo before exerting their antifertility action (Ford et al., 1981). It is feasible that they could be degraded to $(R) 3$-chlorolactaldehyde which has been proposed as an active metabolite of $\alpha$-chlorohydrin (A. R. Jones, personal communication) but that spermatozoa themselves are not capable of catalysing all the necessary reactions.

The relative potency of the compounds in producing spermatocoeles reflected their activity as reversible antifertility agents. Therefore it is likely that these two effects are produced by the same or by related metabolites. If this is so it will not be possible to synthesize a compound which can produce only the reversible effect. However, $\alpha$-chlorohydrin does not produce spermatocoeles in species other than the rat (Kirton et al., 1970) so this effect may not completely rule out the use of these compounds.

By contrast the efficacy of the compounds as reversible contraceptives in the rat was not related to their relative neurotoxicity in the mouse. This is best illustrated by comparing 6-chloro-6-deoxymannose and 6-chloro-6-deoxyglucose; the antifertility doses of these compounds in the rat are the same $(24 \mathrm{mg} / \mathrm{kg} /$ day) but 2.5 times more 6 -chloro-deoxymannose than 6-chloro-6-deoxyglucose is required to produce a similar incidence of neurotoxicity in the mouse. This suggests that unrelated metabolites may be responsible for the antifertility effect and the neurotoxic effect. $\alpha$-Chlorohydrin is metabolized by at least 2 pathways (see Jones, 1978), and compounds with an improved ratio of antifertility to neurotoxic activity could presumably be produced. However, the data could also be explained by species differences in the pharmacokinetics of the two 6-chloro-6-deoxysugars between rats and mice. Although the positive control groups suggest that visible paralysis was an equally effective screen of neurotoxicity in all groups, the histological damage in mice given 6-chloro-6-deoxyglucose (480 $\mathrm{mg} / \mathrm{kg} /$ day) was as extensive in the animals which showed paralysis and those which did not (Jacobs \& Ford, 1981).

We thank Dr E. B. Rathbone and Dr P. J. Simpson of the Philip Lyle Memorial Research Laboratory for the supply of materials and for discussion; Miss Anne Harrison for the 
biochemical measurements; and Miss Pam Rummings for assistance with the animal experiments. The work was supported by Grant No. 77127 from the World Health Organisation.

\section{References}

Brown-Woodman, P.D.C., Mohri, H., Mohri, T., Suter, D. \& White, I.G. (1978) Mode of action of $\alpha$-chlorohydrin as a male antifertility agent. Biochem. J. 170, 23-27.

Ford, W.C.L. \& Waites, G.M.H. (1978a) A reversible contraceptive action of some 6-chloro-6-deoxysugars in the male rat. J. Reprod. Fert. 52, 153-157.

Ford, W.C.L. \& Waites, G.M.H. (1978b) Chlorinated sugars: a biochemical approach to the control of male fertility. Int. J. Androl., Suppl. 2, 541-564.

Ford, W.C.L. \& Waites, G.M.H. (1981) The effect of high doses of 6-chloro-6-deoxyglucose on the rat. Contraception (in press).

Ford, W.C.L., Harrison, A. \& Waites, G.M.H. (1977) Effects of the optical isomers of $\alpha$-chlorohydrin on glycolysis by ram testicular spermatozoa and the fertility of male rats. J. Reprod. Fert. 51, 105-109.

Ford, W.C.L., Harrison, A., Takkar, G.L. \& Waites, G.M.H. (1979) Inhibition of glucose catabolism in rat, hamster, rhesus monkey and human spermatozoa by $\alpha$-chlorohydrin. Int. J. Androl. 2 , 275-288.

Ford, W.C.L., Harrison, A. \& Waites, G.M.H. (1981) Effects of 6-chloro-6-deoxysugars on glucose oxidation in rat spermatozoa. J. Reprod. Fert. 63, $67-73$.

Heitfeld, F., McRae, G. \& Vickery, B. (1979) Antifertility effects of 6-chloro-6-deoxyglucose in the male rat. Contraception 19, 543-556.

Hoffer, A.P., Hamilton, D.W. \& Fawcett, D.W. (1973) The ultrastructural pathology of the rat epididymis after administration of $\alpha$-chlorohydrin (U-5897). Anat. Rec. 175, 203-230.

Hohorst, H.J. (1963) L(+) lactate. In Methods of Enzymatic Analysis, Vol. II, pp. 266-270. Ed. H. U. Bergmeyer. Verlag Chemie, Weinheim.
Hutton, P., Dawson, A.G. \& Jones, A.R. (1980) Inhibition of glycolysis in boar sperm by $a-$ chlorohydrin. Contraception 22, 505-512.

Jackson, H. \& Robinson, B. (1976) The antifertility effects of $\alpha$-chlorohydrins and their stereo-isomers in male rats. Chem. Biol. Interactions 13, 193-197.

Jackson, H., Rooney, F.R., Fitzpatrick, R.W. \& Gibson, K.H. (1977) Characterisation and antifertility activity in rats of $S(+) \alpha$-chlorohydrin. Chem. Biol. Interactions 17, 117-120.

Jacobs, J.M. \& Duchen, L.W. (1980) Effects of 6-chloro-6-deoxyglucose on the nervous system of the marmoset. Neuropath. A ppl. Neurobiol. 6, 236237.

Jacobs, J.M. \& Ford, W.C.L. (1981) The neurotoxicity and antifertility properties of 6-chloro-6deoxyglucose in the mouse. Neurotoxicology 2, $405-418$.

Jones, A.R. (1978) The antifertility actions of $\alpha$ chlorohydrin in the male. Life Sci. 23, 1625-1646.

Jones, A.R., Porter, K. \& Stevenson, D. (1981) The renal toxicity of some halogenated derivatives of propane in the rat. Naturwissenschaften 68, S. 98.

Kirton, K.T., Ericsson, R.J., Ray, J.A. \& Forbes, A.D. (1970) Male antifertility compounds. Efficacy of U-5897 in primates (Macaca mulatta). J. Reprod. Fert. 21, 275-278.

Samojlik, E. \& Chang, M.C. (1970) Antifertility activity of 3-chloro-1,2-propanediol (U-5897) on male rats. Biol. Reprod. 2, 299-304.

Sweeley, C.C., Bentley, R., Makita, M. \& Wells, W.W. (1963) Gas liquid chromatography of trimethylsilyl derivatives of sugars and related substances. J. Am. Chem. Soc. 85, 2497-2507. 